\title{
Correction to: Risk factors for mortality in hospitalized patients with COVID-19 at the start of the pandemic in Belgium: a retrospective cohort study
}

Karlijn van Halem ${ }^{1 *}$, Robin Bruyndonckx ${ }^{2,3}$, Jeroen van der Hilst ${ }^{1,4}$, Janneke Cox ${ }^{1,4}$, Paulien Driesen ${ }^{1}$, Matthias Opsomer ${ }^{1}$, Eveline Van Steenkiste ${ }^{1}$, Björn Stessel ${ }^{5}$, Jasperina Dubois ${ }^{5}$ and Peter Messiaen ${ }^{1,4}$

\section{Correction to: BMC Infect Dis (2020) 20:897 https://doi.org/10.1186/s12879-020-05605-3}

Following publication of the original article [1], the authors identified an error in the caption of Fig 2. The correct caption is given below .

The incorrect caption is: "Admission early in the epidemic versus later in the epidemic".

The correct caption is: "Multivariate analysis of risk factors for death versus hospital discharge".

The original article [1] has been updated.

\begin{abstract}
Author details
'Department of Infectious Diseases and Immunity, Jessa Hospital, Stadsomvaart 11, 3500 Hasselt, Belgium. ${ }^{2}$ Interuniversity Institute for Biostatistics and statistical Bioinformatics (I-BIOSTAT), Data Science Institute (DSI), Hasselt University, Hasselt, Belgium. ${ }^{3}$ Laboratory of Medical Microbiology, Vaccine \& Infectious Disease Institute (VAXINFECTIO), University of Antwerp, Universiteitsplein 1, 2610 Antwerp, Belgium. ${ }^{4}$ Faculty of Medicine and Health Sciences, Hasselt University, Hasselt, Belgium. ${ }^{5}$ Department of Intensive Care Jessa Hospital, Hasselt, Belgium.
\end{abstract}

Published online: 14 December 2020

\section{Reference}

1. van Halem $\mathrm{K}$, et al. Risk factors for mortality in hospitalized patients with COVID-19 at the start of the pandemic in Belgium: a etrospective cohort study. BMC Infect Dis. 2020;20:897 https://doi.org/10.1186/s12879-02005605-3.

The original article can be found online at https://doi.org/10.1186/s12879 020-05605-3.

* Correspondence: karlijn.vanhalem@jessazh.be

${ }^{1}$ Department of Infectious Diseases and Immunity, Jessa Hospital, Stadsomvaart 11, 3500 Hasselt, Belgium

Full list of author information is available at the end of the article

(c) The Author(s). 2020 Open Access This article is licensed under a Creative Commons Attribution 4.0 International License, which permits use, sharing, adaptation, distribution and reproduction in any medium or format, as long as you give appropriate credit to the original author(s) and the source, provide a link to the Creative Commons licence, and indicate if changes were made. The images or other third party material in this article are included in the article's Creative Commons licence, unless indicated otherwise in a credit line to the material. If material is not included in the article's Creative Commons licence and your intended use is not permitted by statutory regulation or exceeds the permitted use, you will need to obtain permission directly from the copyright holder. To view a copy of this licence, visit http://creativecommons.org/licenses/by/4.0/. The Creative Commons Public Domain Dedication waiver (http://creativecommons.org/publicdomain/zero/1.0/) applies to the data made available in this article, unless otherwise stated in a credit line to the data. 